\title{
Interpretation of Judges Toward Fasid and Batil Marriage
}

\author{
Fitri Hidayat, SH., MH \\ Faculty of Law Universitas Brawijaya, Indonesia \\ fitri.hidayat@ub.ac.id
}

\begin{abstract}
Legal marriage in Islam is in accordance with the pillars and conditions. The pillars and conditions are fulfilled, then a marriage is considered as legitimate. This research will look at several court stipulation and decisions relating to this matter. Stipulation of Religious Court of Bangli Number 01/Pdt.P/2011/PA.Bgl, Decision of Religious Court of Denpasar Number 50/Pdt.G/2011/PT.Dps Stipulation of Religious Court of Polewali Number 93/Pdt.P/2016/PA.Pwl, Stipulation of Religious Court of Banjarbaru Number 80/Pdt.P/2017/PA.Bjb, Stipulation of Religious Court of Banjarbaru Number 179/Pdt.P/2017/PA.Bjb, Stipulation of Religious Court of Number 182/Pdt.P/2017/PA.Bjb, Decision of Religious Court of Pekanbaru Number 0042/Pdt.G/2017/PTA.Pbr.

The stipulation and decision are different in material requests and claims, but the focus is on the interpretation of judges about the legitimacy of marriage, which then discusses fasid marriage and batil marriage. A broken marriage because the pillars and conditions are not appropriate. The judge views the greatest importance, namely the interests of the child so that in his decision, even though the marriage is fasid the child remains legitimate child. According to researchers in the stipulation and decision there are marriages that should be interpreted as batil, but interpreted as fasid. The judge interprets all illegitimate marriages as fasid marriages even though they are supposed to be batil. Because what is not fulfilled is the pillar. The judge uses the views of the Hanafi madzab to interpret. The judge does this because he emphasizes the best interests of the child so that no child is considered child out of marriage. The judge only thinks about the interests of the children civil rights that are born in illegitimate marriage. The judge in deciding also put forward the sharia maqasid. Judges here use teleological interpretations as well as extensive interpretation by expanding the meaning of fasid marriage.
\end{abstract}

Keywords: Interpretation of judges, marriage law, batil marriage

\section{INTRODUCTION}

Legitimate requirements for marriage in Law Number 1 of 1974 concerning Marriage (hereinafter) referred to as the Marriage Law) are explained in article 2, namely marriage conducted in accordance with religious law and recorded. So to be called a marriage that is considered legitimate by the state, the Marriage Law returns to the respective religious laws. When it has been carried out in accordance with the pillars and the conditions in the religion and then recorded it is what is deemed valid by the state. In this study also will discuss the legal requirements of marriage, especially in Islamic marriages. Islamic marriage considers that the legitimacy of marriage when the fulfillment of pillars and conditions of marriage.

According to Law No. 3 of 2006 on the amendment of Law No. 7 of 1986 on the Religious Court (hereinafter to be referred to the Law on Religious Court) that the competence of religious court in solving the case of marriage for the citizens who are Muslim in this case, including the cancellation of the marriage also the determination of the origin of child. In addition to the Marriage Law which is used as legal basis for deciding cases in marriage, Religious Court Judges also use Presidential Instruction No. 1 of 1991 concerning 
Compilation of Islamic Law (hereinafter referred to as KHI) as legal basis. This KHI is collection of Islamic law written in the form of articles per article which is then used by Religious Court Judges as guideline when completing cases that enter the Court. Although in the hierarchy of KHI legislation it does not include in it, but the Religious Court Judge to date still uses KHI as guideline because it regulates more specifically material regarding Islamic law. Even so it is not prohibited also when the Religious Court Judge does not use KHI as guideline.

According to the Marriage Law Article 22 states that, "Marriage can be canceled if the parties do not fulfill the conditions for carrying out marriage." Marriage cancellation is regulated in Article 22-28 of the Marriage Law. According to Islamic law, marriage is considered valid if marriage contract has been fulfilled the pillars and the conditions and contained no marriage prohibition element on the bride. In addition, marriage is basically canceled because the pillars are not fulfilled and the marriage is not fulfilled the conditions are fasad (broken). ${ }^{1}$

Marriage cancellation was once regulated also in the Civil Code in articles 85-99a. According to article 85 of the Civil Code "The marriage cancellation can only be declared by the Judge. "Marriage cancellation that goes contrary to article 27 of the Civil Code because marriage more than one husband/wife can be sued by person who because of previous marriages had bonded with one of the spouses, the spouses themselves, or by the one blood family in straight line upwards, or by those concerned over previous marriage nullification disputed, it must be solved first, about the validity of the marriage. ${ }^{2}$

In Law Number 1 of 1974 concerning Marriage, it is also regulated in Article 26 and 27 reasons that can be submitted for marriage cancellation, namely as follows:

1. Marriage that takes place before an unauthorized marriage registrar.

2. The marriage guardian who does the marriage is not legal.

3. Marriage was held without 2 (two) witnesses.

4. Marriage is carried out under threats that violate the law.

5. When the marriage took place there is misinterpretation about the husband or wife. For example, a husband thinks his wife is real woman, but it turns out that his wife is male sex.

For reasons in number 1-3 the marriage cancellation can be submitted by families in a upward straight line lineage from husband or wife, prosecutor and husband or wife. But the right to dissolve marriage by husband or wife are void if they have been living together as husband and wife and to show the marriage certificate made by an unauthorized marriage registrar and marriage must be renewed so that it is valid. This is explained in article 26 paragraph (1) and (2) Law No. 1 of 1974 concerning Marriage. Whereas for reasons number 4 and 5 it can be proposed to cancel the marriage by husband or wife if the marriage takes place under a threat that violates the law, or when the marriage takes place there is mistake about the person.

In the Compilation of Islamic Law there are also rules governing the reasons for the marriage cancellation. These reasons are explained in Article 70 and Article 71 Compilation of Islamic Law. Reasons mentioned in Article 70 Compilation of Islamic Law is the reason

\footnotetext{
${ }^{1}$ Indah Purbasari, Islamic Law as a Positive Law in Indonesia, Setara Press, Malang, 2017, p. 122

${ }^{2}$ Hilman Hadikusuma, Marriage Law Indonesia, Mandar Maju, Bandung, 2007, p 75.
} 
for marriage which is immediately null and void by law. While the reasons stated in Article 71 of the Compilation of Islamic Law are reasons for irrevocable marriage. In the sense that if the reason is never raised or uttered by the person concerned, the marriage is not void.

Marriage cancellation also carried out on marriage that is not recorded. It is considered in marriage ithbat where the husband and wife who don't not registers their marriages to appeal to the Religious Court to certify the marriage. In consideration of the marriage ithbat petition law that the judge consider whether the marriage can be validated or canceled. Therefore the annulment of marriage does not only apply to marriages which are listed but fulfill the conditions for the marriage cancellation, but also to marriages that are not listed and fulfill the conditions or conditions for the marriage cancellation.

In Law Number 1 of 1974 concerning Marriage, Polygamy is permitted under Article 3 paragraph (2) where Article 4 and Article 5 regulate requirements if a husband will have more than one wife. One of the conditions listed in Article 5 of Law Number 1 Year 1974 concerning Marriage is to say that the husband must obtain approval from his previous wife or wives. That is why marriage can be canceled if the previous wife made lawsuit to the Court. Marriage is not null and void but there must be a lawsuit beforehand to the Court.

Legal marriage in Islam is in accordance with the pillars and conditions. Pillars and conditions are fulfilled, then marriage is considered as legitimate. Pillars in Islamic marriage are the presence of prospective husbands, prospective wives, the presence of guardians, the presence of witnesses, and the existence of ijab qabul. So that when the pillar is not fulfilled it includes batil marriage. Of course the 5 pillars that exist have to be dissected again, what prospective husbands, what prospective wives. Then the fasid marriage is defined as a marriage that does not fulfill the conditions, meaning things outside the contract. Indeed, the difference between the batil marriage and fasid marriage is very thin.

In this regard, the focus of this research is to look at the interpretation of judges of fasid marriage and batil marriage. This research will look at several court decisions and decisions relating to this matter. Stipulation and determination are:

a. Stipulation of Religious Court of Bangli Number 01/Pdt.P/2011/PA.Bgl.

b. Decision of Religious Court of Denpasar Number 50/Pdt.G/2011/PT.Dps.

c. Stipulation of Religious Court of Polewali Number 93/Pdt.P/2016/PA.Pwl.

d. Stipulation of Religious Court of Banjarbaru Number 80/Pdt.P/2017/PA.Bjb

e. Stipulation of Religious Court of Banjarbaru Number 179/Pdt.P/2017/PA.Bjb.

f. Stipulation of Religious Court of Banjarbaru Number 182/Pdt.P/2017/PA.Bjb.

g. Decision of Religious High Court of Pekanbaru Number 00 42/Pdt.G/2017/PT A.Pbr.

The stipulation and decision are different in material requests and claims, but the focus is on the interpretation of judges about the legitimacy of marriage, which then discusses fasid marriage and batil marriage. Broken marriage because of the conditions and pillars not appropriate. The judge views the greatest importance, namely the interests of the child so that in the decision even though the marriage is fasid the child remains legitimate child. According to researchers in the stipulation and decision there are marriages that should be interpreted as batil, but interpreted as fasid. Because this fasid marriage and batil marriage are different so the legal consequences caused by both are also different. 


\section{LEGAL MATERIALS AND METHODS}

\section{RESULT AND DISCUSSION}

\section{Fasid Marriage}

Fasid is something that is mandated its essences, not in nature, that is, something that loses one of several conditions. If defect occurs outside the pillar of marriage, it is called fasid (broken). ${ }^{3}$ Fasid marriage is marriage that partially damaged its requirements, but legitimate. Only need to be repaired. Some scholars give examples of broken marriages that if man gives dowry in the form of pork, such as the marriage is legitimate, but the dowry should be replaced with halal dowry. Because dowry must not be from something or result of forbidden thing. ${ }^{4}$ If someone is married and the marriage contract is fasid, then it is obligatory to separate because the law is immoral. Married couples should separate from their own consciousness, because they are not justly justified. If it does not separate from its own consciousness, it must be settled by those who know. Because the marriage is fasid, there is no stipulation of inheritance rights between the partners, there is no obligation to support, there is no obligation to give place to live and there is no obligation to obey the husband. According to the scholars who are classified as fasid marriages are syighar marriages (conditional marriages), muhallil marriage, mut'ah marriage.

\section{Batil Marriage}

Batil is all akad that has disability, and disability occurs at the pillars, in this case is marriage pillars. Ulama agreed that batil marriage included:

1. Mary one of the mahram

2. Marriage of Muslim men with non- ahli Kitab musyrikah women

3. Marriage of Muslim women with non-Muslim men

4. Mut'ah marriage

5. Marriage without guardians and witnesses, or marriage only together with witnessed walls and roofs but intended to be lasting, not mut'ah contract marriage.

6. Fifth marriage for those who still have four legal wives.

7. Combine two sisters or women with their aunts

8. Marry women who are still other wife or within the prescribed period.

\section{Analysis of Decisions}

In this study researchers used at least 7 (seven) legal materials including decisions and stipulations. This decision and stipulation is to seek the interpretation of the judge of marriage. The judge interprets what fasid marriage and batil marriage are.

\section{1) Stipulation of Religious Court Bangli of Number 01/Pdt.P/2011/PA.Bgl.}

\footnotetext{
${ }^{3}$ Abdul Aziz Muhammad Azzam and Abdul Wahab Sayyed Hawwas, Fiqh Munakahat (Khitbah, Marriage, and Divorce), Jakarta, Amzah, 2011, p. 132

${ }^{4}$ Ahmad Zain An Najah, Marriage that is considered Damaged According to Syara', www.masjidKu.id, accessed on March 3, 2018 at 12:16
} 
The husband and wife married with unauthorized guardian, trustee actually still there but the marriages were passed off to other people and that marriage is not recorded. When the child is born, the husband and wife request the Court to determine the origin of the child so that they can make a birth deed. The judge in his legal considerations stated that the marriage was fasid, considered as broken marriage. But the child born in the marriage must be offered to his father. The judge in his consideration uses the basis:

Book by Dr. Wahbah al- Zuhaili, namely al- Fiqh a- Islami wa Adillatuhu, volume VII, second print issued by Dar al- Fikr Damascus in 1995 page 690 which is taken over as the opinion of the Panel of Judges themselves, namely as The following: "Marriage, both legal and fasid, is a cause for set the nasab in a case. So if there has been a real occurrence marriage, even though the marriage is fasid (broken) or a marriage is done by custom, which occurs with certain (traditional) contract methods without being registered in the official marriage certificate, it can be stipulated that the born child nasab by the woman as a child from the husband and wife (concerned)."

\section{2) Decision of High Religious Court of Denpasar Number 50/Pdt.G/2011/PT.Dps.}

The husband and wife married without the permission of her husband's first wife, also without the knowledge of the first wife. The first wife submitted the cancellation of the second marriage of the husbands to the Court. The marriage with illegal guardian. The judge cancels the marriage in consideration of the illegal guardian.

\section{3) Stipulation of Religious Court of Polewali Number 93/Pdt.P/2016/PA.Pwl.}

Husband and wife asks marriage ithbat because the marriage is not recorded. When marriage is not attended by a guardian, the guardian of the marriage at that time was an Imam in a mosque. The judge rejected the request marriage ithbat on the basis that his marriage guardian is not clear and the marriage is considered batil.

\section{4) Stipulation of Religious Court of Banjarbaru Number 80/Pdt.P/2017/PA.Bjb}

Husband and wife request the determination of the origin of the child so that they can make a birth deed for the child. Married husband and wife is not listed, and in the trial found that the wife had not formally divorced her first husband, so the status is still married to someone else. The judge determines the origin of the child considering that the marriage of his parents is indeed considered fasid, but the child must be disbursed to his father, so that the judge grants it.

\section{5) Stipulation of Religious Court of Banjarbaru Number 179/Pdt.P/2017/PA.Bjb.}

The husband and wife request the determination of the origin of the child so that they can get a birth deed. But in the trial it was found that the fact that his parents were married was not recorded and that his wife was still in the midst of marriage with his previous husband. The judge determines the fasid marriage. But the child is still offered to his father.

\section{6) Stipulation of Religious Court of Banjarbaru Number 182/Pdt.P/2017/PA.Bjb.}

The husband and wife request the determination of the origin of the child so that they can get a birth deed. But in the trial it was found that the fact that his parents were married was not recorded and that his wife was still in the midst of a marriage with his previous husband. The judge determines the fasid marriage. But the child is still offered to his father. The judge here looks exactly the same verdict with the previous judge for the case where the position of the case is the same, also from the same court.

7) Decision of Religious High Court of Pekanbaru Number 0042/Pdt.G/2017/PTA.Pbr. 
Married husband and wife are not listed and use unclear guardians. Then the marriage was requested cancellation by the husband's first wife, because there was no permission from the first wife. The judge canceled the marriage and upheld the previous judge's decision. The marriage is considered fasid.

From 7 (seven) legal materials, the stipulation and decision above shows a pattern. Almost all judges if it concerns a child, the judge will prioritize the interests of the child. Seen in the decisions number $1,4,5$, and 6 . The judge determines that the child is still assigned to his father. Although besides that the judge also determined that the marriage was classified as fasid marriage. If it is classified as fasid marriage, then the condition is deemed damaged. The marriage is considered fascic but not batil. So that the derivative law is considered valid. Because of that, the issue of nasab, a child can also be designated as his father's son or given to his father. This is good because there is a greater interest in the interests of the child. So that children can get their civil rights. Even if you look back at decisions number 1, 4.5, and 6 classified as batil marriage, it is not only broken on the terms but the pillars. In the decision number 4.5 and 6 most visible, that marriage occurs when the wife is still the status of the wife of the person and the other is still in the iddah period. This condition is defined as batil marriage because the legal basis is clear that it is not permissible to marry a woman who is still a wife or who is still in the iddah period. Rules regarding the period of time are listed in article $153 \mathrm{KHI}$ which states that:

"(1). For a wife who broke up his marriage applicable waiting period or waiting period, except qobla al dukhul and his marriage broke up not because of the death of the husband.

(2). The waiting time for a widow is determined as follows: a. When the marriage broke up because of death, although qobla al dukhul, timeout is set 130 (one hundred and thirty) days: b. If the marriage is terminated due to divorce, the period for those who are still menstruating is determined to be 3 (three) times sacred with at least 90 (ninety) days, and for those who do not menstruate, 90 (ninety) days; c. If the marriage is terminated because the divorce is being widowed, the waiting time is set until delivery; d. If the marriage breaks due to death, while the widow is pregnant, the waiting time is set until delivery.

(3). There is no waiting time for those who break up because of a divorce between widows with her ex-husband qobla al dukhul.

(4). For marriages that break up due to divorce, the waiting period is calculated from the fall, the Religion Court Decision has a permanent legal force, while for the marriage that is terminated due to death, the waiting period is calculated from the death of the husband.

(5). The waiting time for menstruating wives is currently undergoing iddah not menstruating because of breastfeeding, then the period is three times during menstruation.

(6). In the case of a state in paragraph (5) not because of breastfeeding, then the iddah for one year, but if within a year she had her period again, then the iddah be thrice holy time."

So obvious when a woman divorced by her husband then prevails the prescribed period for women. So that when the woman wants to get married again must wait for the iddah 
period to be finished. Wife liabilities during the prescribed period is not be groom by other men either openly or by innuendo, but for women who undergo idda for husband's death the proposal can be done by innuendo. The reason ulama fiqh establishes this law is the word of Allah in Surat Al- Baqarah verse 235:

"And there is no sin for you to propose those women with satire or you hide (the desire to marry them) in your heart. God knows that you will mentioning they are, in the meantime do not hold their promise to marry in secret, except just to say (to them) ma'ruf words. And do not make 'azam for to make marriage akad, before the expiry of the iddah and know it that Allah knows what is in your heart; So fear Him, and know that Allah is Forgiving, Most Forbearing".

In Marriage Law is in article 11 which stipulates that a woman who breaks her marriage has waiting period. Then the waiting time referred to in the Marriage Law is regulated in the PP Implementation of the Marriage Law. Article 39 PP Implementation of the Marriage Law regulates:

(1) The waiting time for a widow as referred to in Article 11 paragraph (2) of the Law is determined as follows: a. If the marriage breaks due to death, the waiting time is set to 130 (one hundred and thirty) days b. If the marriage breaks up due to divorce, the waiting time for those who are still coming months is determined to be 3 (three) holy times with at least 90 (ninety) days and for those who do not arrive the month is set 90 (ninety) days; c. If the marriage is broken while the widow is pregnant, the waiting time is set until delivery.

(2) There is no waiting time for widows who drop out of marriage because a moderate divorce between the widow and her ex-husband has never had sex.

(3) For marriages that break up due to divorce, the waiting period is calculated from the fall of the Court's decision which has a permanent legal force, while for the marriage that is terminated due to death, the waiting period is calculated from the death of the husband.

The researcher interprets article 11 of the Marriage Law prohibiting women who are still in the iddah period for remarriage, meaning women may remarry after the iddah period is over. Then in addition to the Marriage Law and the PP Implementation of the Marriage Law, KHI also regulates the period of the period in article 153, the content of which is the same as the article in the Marriage Law, only the language or term used in accordance with Islamic marriage. The contents of the article are:

"(1). For a wife who broke up his marriage applicable waiting period or waiting period, except qobla al dukhul and his marriage broke up not because of the death of the husband.

(2). The waiting time for a widow is determined as follows: a. When the marriage broke up because of death, although qobla al dukhul, timeout is set 130 (one hundred and thirty) days: b. If the marriage is terminated due to divorce, the period for those who are still menstruating is determined to be 3 (three) times sacred with at least 90 (ninety) days, and for those who do not menstruate, 90 (ninety) days; c. If the marriage is terminated because the divorce is being widowed, the waiting time is set until delivery; d. If the marriage breaks due to death, while the widow is pregnant, the waiting time is set until delivery. 
(3). There is no waiting time for those who break up because of a divorce between widows with her ex-husband qobla al dukhul.

(4). For marriages that break up due to divorce, the waiting period is calculated from the fall, the Religion Court Decision has a permanent legal force, while for the marriage that is terminated due to death, the waiting period is calculated from the death of the husband.

(5). The waiting time for menstruating wives is currently undergoing iddah not menstruating because of breastfeeding, then the period is three times during menstruation.

(6). In the case of a state in paragraph (5) not because of breastfeeding, then the iddah for one year, but if within a year she had her period again, then the iddah be thrice holy time."

The rules regarding the above case are actually very clear, especially in Article 40, KHI says that: There is no prohibition between a man and a woman because of certain conditions: a. because the woman in question is still tied to one marriage with another man; $b$. a woman who is still in iddah time with another man; c. a woman who is not Muslim. Then in other hadiths, namely:

Atsar narrated from Umar bin Khattab - radi 'anhu - The above means that if he was married before the completion of the iddah, then he is two things: First, implement ceremony but not intercourse: Mandatory separated, improve time the iddah, and for the second husband (new) may marry him. Secondly, implement the marriage ceremony and had intercourse, then it must also be separated, and she finished her iddah from her first husband, then continued the prescribed period of the second husband, and forbidden for him to marry again forever, this opinion is Malikiyah madzhab and one of the Hanabilah opinions, while according to the jumhur of the ulama of the madzhab Hanafiyah, Syafi'iyah and Hanabilah they argue that for the second husband (new) still be allowed to marry again after the iddah period has passed ". But Hanabilah added and said: "It is not permissible to marry her again except after the passage of the two iddah periods, iddah from the previous husband and the iddah from the second husband". Mentioned in Mathalib Ulin Nuha: "For those who have married her second husband during the iddah (from her previous husband) and have made love, can marry again after the passage of two prescribed period; because prior to the completion of the prescribed period of her first husband she had married and went on a prescribed period of others, while awaiting the completion of the prescribed period the second husband because the waiting are not qualified, and the marriage did not have any impact, but the prescribed period is the right of the child then he not be married in the future as in the past en dah others ".

So clearly from the discussion above, the core of all the rules is that women who are married at the time of their legal completion period are batil, so if the marriage has occurred the couple must be separated and continue the period of the first husband's term.

But the judge in the stipulation uses the consideration of this hadith:

Kitab al- Fiqh al- Islami wa there is temperature, jld. 7, p. 109-111 which is subsequently taken over as the court apparatus as follows: Fasid marriage according to the School Hanafi is a marriage that is not fulfill one of the legal requirements for marriage. The type of marriage that is categorized fasid according to the School Hanafi is as follows; 1). marriage without a witness; 2). marriage contract; 3). marry a woman more than 4 (four) 
people at one time; 4). married two the sisters simultaneously, married to wife and simultaneously good aunt paternal aunt or aunt on the mother's side; 5). marry a woman without knowing that the status is still the wife of another person (polyandry); 6). Married mahram despite knowing that it is not allowed.

So that the debate also occurs between the hadith one with another hadith. There are still differences of opinion also from Islamic scholars interpret the imperfect marriage and marriage this batil. Because the schools used are different, they will produce different conclusions.

Likewise with marriage without guardian as in the position number 1 case. Marriage without guardian should be classified as batil marriage because it clearly violates harmonious marriage. In Islamic marriage harmonious must be fulfilled, and the marriage guardian is included in harmony. Researchers interpret the marriage without a guardian is not at all attended guardian or guardian but the real guardian was still alive and had not been told, so the guardian unauthorized use. Whatever the researchers interpret the goal must be bad because if nothing was hidden for any unauthorized use of guardians. Because when couples who want to get married then use unauthorized guardians must knowingly do that and there must be an element of intent. Then the researchers interpret it as marriage without a guardian. If based on the hadith This messenger of Allah is very clear that marriage without a guardian is clearly legal.

From Aisha RA. Rasulullah saw. said it was illegal to marry without a guardian and two witness person, if marriage is not so, then he is batil (illegitimate) and if the guardian disagree with the ruler for people who have no guardian;

Whereas on the one hand the judge also uses this hadith as a basis:

Jurisprudence Rule in the Kitab Al Iqna ' Juz II page 123 is taken over as the opinion of the assembly: there are five pillars of marriage, namely sighat (ijab) qabul), prospective wives, prospective husbands, guardians, both of whom carried out the marriage contract and two witnesses.

Then about children born to marriages that are considered fasid still can said to his father, because of the marriage that his mother's father considered damaged and must be repaired. But if the marriage is batil then it must be interpreted illegitimate, it will also affect the child's nasab. Children as part of the main human resources of a generation of the nation is a mandate as well as the gift of God Almighty, which must always be guarded because it is inherent in itself dignity and rights as human beings that must be upheld. Children's rights are part of human rights contained in the 1945 Constitution and the United Nations Convention on the Rights of the Child. ${ }^{5}$ Dr. Wirjono in his book Inheritance Law in Indonesia, among others states that because they (the children) in essence are the only class of heirs, meaning that relatives do not become heir when the inheritance left a legacy of children. ${ }^{6}$ There are several types of child status categories in the legislation, namely legal children, children outside of marriage, stepchildren, and adopted/adopted children. The difference in the category of children has a large influence on matters relating to family law such as inheritance and also guardian of marriage.

\footnotetext{
${ }^{5}$ I Nyoman Sujana, op.cit., P. 145

${ }^{6}$ Soedharyo Soimin, Law of People and Family, Sinar Grafika, Jakarta, 2010, p. 31
} 
Position of child in Burgerlijk Wetboek (BW), better known as the Civil Code, is divided into two, namely legal children and extramarital children. The provision of Article 250 BW states: " Every child born or grown throughout marriage gets a husband as his father. " The provisions of the article can be concluded that legitimate children are children born or children grown in a marriage and get the husband as his father, and the reverse understanding of the formulation of the article above is categorized as illegitimate children or out-ofmarriage children. ${ }^{7} \mathrm{BW}$ divides out-of-marriage children into 3 (three) groups, namely adultery children, discordant children and out-of-wedlock children. Bastard according to civil law principles west are children born of the relationship between a man and a woman that one or both are bound by marriage with other, it is as a consequence of the principle of monogamy adopted by BW. Whereas discordant children are children born from the relationship between men and women where the law prohibits marriage between them, for example because they are still bound by blood relations. Whereas other out-of- wedlock children are children who are cultured or born outside the marriage of his parents but can be recognized by his parents. ${ }^{8}$ Article 43 paragraph (1) of Law Number 1 of 1974 concerning Marriage does not provide an understanding of what is meant by extramarital children. Based on interpretation a contrary by adhering to the formulation of Article 42 of Law Number 1 concerning Marriage, it can be formulated that including out-of-wedlock children, namely children not included in the three categories of legitimate children as stipulated in Article 42 of Act Number 1 concerning Marriage, namely:

1. Legitimate children who are cultured and born in legal marriages.

2. Children who are cultured before marriage and are born in a legal marriage.

3. Children who are cultured in marriage are legitimate and are born after the marriage breaks up. ${ }^{9}$

Whereas in Article 99 the Compilation of Islamic Law for the rites of legitimate children is mentioned as follows:

1. Children born within or due to legal marriage.

2. Result of a legitimate husband and wife outside the womb and being born by the wife.

Offspring rearing is the rearing and protection of every child with clear status, must be treated as part of the community that must grow and develop around their parents, both physically and spiritually. To guarantee the rearing of these offspring in Islamic Law it is forbidden to engage in husband and wife relations outside of marital ties. ${ }^{10}$ In his position as a legitimate child, certainly it will have juridical consequences. The legal outcome of a legal child is that this child has a civil relationship with his parents and his parents' family. As a result of the relationship, the obligation arises to maintain each other. In addition, due to the juridical status of children, it is also closely related to inheritance. According to the researcher, this is not appropriate considering that legitimate children are children born from legitimate marriages in accordance with Article 42 of Law Number 1 Year 1974 concerning Marriage and Article 99 Compilation Islamic law. Legitimate marriage itself according to Article 42 of Act Number 1 of 1974 and Article 99 Compilation of Islamic Law is marriage conducted in

\footnotetext{
${ }^{7}$ Ibid., P. 63

${ }^{8}$ Ibid., P. 64

${ }^{9}$ Ibid., P. 175-176

${ }^{10}$ Aulia Muthiah, op.cit., P. 192
} 
accordance with Article 2 paragraph (1) of Law Number 1 of 1974 concerning Marriage. If the marriage violates the laws of each religion, it is clear that the marriage is an illegitimate marriage which should be the child of the marriage to be an illegitimate child.

Regarding the illegitimate child or children outside of the marriage then prevail the Constitution Court regarding the relationship civil illegitimate children or children outside of mating in which the decision states that should Article 43 paragraph (1) of Law No. 1 of 1974 About Marriage reads as follows, "Son born outside of marriage has civil relationship with his mother and his mother's family and with men as his father which can be proven based on science and technology and/or other evidence according to the law to have blood relations, including civil relations with his father's family." The Constitution Court decision only changes Article 43 paragraph (1) of Law Number 1 of 1974 concerning Marriage where the article only mentions the civil relationship between mother and father and their child but does not discuss the status of the child. So that the researcher assesses that even though the Constitutional Court Decision is valid, the child remains an illegitimate child but has a civil relationship with his father.

\section{Interpretation of Judges}

After seeing the discussion above, it can be seen that the judges carry out legal interpretations, which can be seen in legal considerations in their stipulations. According to Bagir Manan there are some principles that can diambul of article 10 of Law No. 48 of 2009 on the Powers of Justice, namely: ${ }^{11}$

1. To guarantee legal certainty, that every case submitted to the court will be decided;

2. To encourage judges to make legal discoveries;

3. As a symbol of freedom of judges in deciding cases;

4. As a symbol of the judge does not always have to be bound literally to the existing laws and regulations. The judge can use a variety of ways to achieve justice is right and fair.

A judge has the freedom to make a decision, but in it contains the essence: ${ }^{12}$

1. Judges are only subject to law and justice

2. No one, including the government, can influence the judge's decision

3. There must be no consequences for the judge's personal relationship with his judicial duties

The approach theory used by judges in deciding cases is:

1. Balance Theory

Balance between the requirements in the law and the interests of the parties related to the case. The interests of defendants, plaintiffs, defendants, victims and the public.

2. Theory of Art and Intuition Approach

This is the authority of the judge's discretion in making decisions. The judge will adjust the law to the circumstances of the litigants. Judges' decisions with an art approach are based on intuition. Judges must be careful because this is very subjective.

3. Scientific Approach Theory

${ }^{11}$ Abintoro Pra koso, Law Discovery - System, Method, Flow and Procedure in Finding Law, Yogyakarta, Lak sbang Preesindo, 2016, p. 51

${ }^{12}$ Ibid, p. 196 
That judges in making decisions cannot only be based on instinct, but also based on the scientific insights of judges.

4. Experience Approach Theory

The more experienced judges are also more careful in deciding a case.

\section{Ratio Decidendi Theory}

Legal provisions created by the court. This theory is based on a basic philosophical foundation, relating to consideration of all the main aspects, namely legal certainty, expediency, humanity.

Legal findings by judges are only needed if the regulations do not yet exist for concrete cases or the rules already exist but are not yet clear. The method of legal discovery by judges can be distinguished in 2 types: ${ }^{13}$

1. Interpretation method

The judge interpreted the law and still adhered to the text of the law.

The types of interpretation methods are:

a. Subsumptive method

The judge applied a text to the law but had not yet entered into complicated reasoning, merely applying syllogism.

b. Grammatical

The judge interprets the words in the law according to the language rules, the rules of the law of grammar.

c. Historical

i. According to the history of the law, it is seeking the intent of the legislators in making the law.

ii. According to legal history that is to understand the law in the context of all legal history.

d. Systematic

Interpreting laws as part of the overall system of legislation.

e. Sociology or Teleology

Establish the meaning of the law based on community goals.

f. Comparative

Comparing between various legal systems. This method is only mainly used in the field of international treaty law.

g. Futuristic

Explain the current law by referring to laws that do not have legal force.

h. Restrictive

Interpretation methods that limit the results of grammatical interpretation.

i. Extensive

The method of interpretation that exceeds the results of grammatical interpretation.

j. Construction method

${ }^{13}$ Achmad Ali, Revealing the Law Veil (A Philosophical and Sociological Study), Jakarta, Chandra Pratama, 1996, p. 167 
The judge conducts logical reasoning to further develop the text of the law. The judge no longer adheres to the sound of the text of the law but also does not ignore the law as a system.

In this case the judge is using a responsive ijtihad method, as described in the book of Legal Discovery by Abintoro Prakoso with a plot such as: ${ }^{14}$

1. Identify and understand contemporary problems that need solutions from aspects of Islamic law. This step needs to be done to find out exactly everything related to contemporary problems that need to be sought solution. This is suitable to be done today because the judge saw so many cases of being pregnant out of wedlock but it was still in the iddah period.

2. Search for and understand the text relating to the problem at hand. In-depth understanding of the meaning of the text that is used as a proposition in a social reality is an initial step that must be done in dialogue with text messages with social reality. Taken by knowing the meaning of the content of the text, knowing the asbabun of nuzul, exploring the interpretation of the cleric on the text and concluding it.

3. Read the text philosophy to find the substance of text messages. In this connection it is important to understand the actual conditions of the community.

4. Seeing maqasid sharia which is to see the purpose of the establishment of Islamic law is to benefit the people.

5. Understanding social reality including social history and opinions of scholars. The factors that need to be considered are social, cultural, scientific and technological progress and more than that must be in accordance with the demands of the times.

6. Responding to the substance of text messages, understanding of maqasid sharia, essentially steps 1 to 5 .

7. Find and establish solutions that are considered correct in response to contemporary problems faced by society. The solution is determined as an answer to the contemporary problem at hand.

Researchers see judges using this method for the above case, seeing the fact that there are many marriages in women who are still tied to the period of birth and have been pregnant first, and especially children born in marriage are illegitimate so the judge sees the maqasid syariah in this case for the sake of the child who is born then the judge grants the petition of the applicant to determine the origin of the child in order to serve his father. For the sake of the interests of children born in batil marriage. In this case the judge applies moral justice and social justice in its stipulation. Judges explore the legal values that exist in society. Judges rely more on moral justice than procedural justice by overriding laws or regulations. ${ }^{15}$ It is not when the judge applies moral justice entirely because of the conscience of the judge, because he thinks of the interests of the child born in the illegitimate marriage but the law that is ruled out is something that is meaningful 'means that the faith is already like that. But with this consideration raises the perception that may be pregnant first before marriage, especially adultery with other men before the end of the period is finished. Then the case of the child

${ }^{14}$ Abintoro Pra koso, Law Discovery - System, Method, Flow and Procedure in Finding Law, Yogyakarta, Lak sbang Preesindo, 2016, p. 191

${ }^{15}$ Ibid, p. 202 
born will be easy to ask for the determination of the origin of the child. In addition, judges use teleological interpretations in this case, namely the judge makes an interpretation of the law according to the current situation or reality of society. Because the reality is a lot married couples who ask for the determination of the origin of the child because the child needs birth. While their marriage is not legal. Extensive interpretation was also carried out by the judge because the judge expanded the meaning of the fasid marriage. Fasid marriage here is interpreted by the judges of all illegitimate marriages, which do not fulfill both harmony and conditions so that all are considered to be fasid marriages. Although there are differences in interpretation between first-level court judges and second-level courts. Second-degree court judges interpret marriages that do not meet the marriage pillars are considered batil marriages, but in cases that do not involve children or not cases that request the determination of the origin of the child.

\section{CONCLUSION AND SUGGESTION}

The judge interprets all illegitimate marriages as fasid marriages even though they are supposed to be batil. Because what is not fulfilled is the pillar. The judge uses the views of the mazhab Hanafi to interpret. The judge does this because he emphasizes the best interests of the child so that no child is considered as child out of wedlock. The judge only thinks about the interests of the birth rights of the child born in an illegitimate marriage. The judge in deciding also put forward the sharia maqasid. Judges here use teleological interpretations as well as extensive interpretation by extending the meaning of fasid marriage.

\section{REFERENCES}

\section{Book}

Achmad Ali, Revealing the Law Veil (A Philosophical and Sociological Study), Jakarta, Chandra Pratama, 1996.

Mr. Martiman Prodjohamidjojo, MM., MA, Indonesian Marriage Law, Jakarta, Indonesia Legal Center Publishing, 2002.

Muhammad Syaifuddin, Sri Turatmiyah, Annalisa Yahanan, Law of Divorce, Jakarta, Sinar Grafika, 2013.

Peter Mahmud Marzuki, Legal Research, Jakarta, Kencana Prenada Group, 2005.

R. Soetojo Prawirohamidjojo, Marthalena Pohan, History of the Development of the Law of

Divorce in Indonesia and the Netherlands, Surabaya, Airlangga University Press 1996.

Soedharyo Soimin, Perspective and Family Law Perspective of West Civil Law/BW, Islamic Law, and Customary Law, Jakarta, Sinar Grafika, 2010.

Soejono and H. Abdurahman, Legal Research Methods, Jakarta, Rineka Cipta, 2003.

Soemiyati, Islamic Marriage Law and Marriage Law, Liberty, Yogyakarta, 1982.

Soepomo, Chapters on Customary Law, Pradnya Pramita, Jakarta, 1989

Taufiqurrohman Syahuri, Marriage Law Legislation in Indonesia, Prenadamedia Gr oup, Jakarta, 2013

Compilation Team, Guidelines for Writing Scientific Work, Malang, Faculty of Law, 2014

Wila Chandrawila Supriadi, Indonesian \& Dutch Marriage Law, Bandung, Mandar Maju, 2002.

Zainuddin Ali, Islamic Civil Law, Jakarta, Sinar Grafika 2006.

\section{Legislation}


Trunojoyo Law Review Vol.1 No.1 2019

Instruction of the President of the Republic of Indonesia Number 1 of 1991 concerning Compilation of Islamic Law

Law Number 1 of 1974 concerning Marriage. State Gazette of 1974 Number 1. Additional State Gazette Number 3019.

Government Regulation Number 9 of 1975 concerning Implementation of Law Number 1 Year 1974 concerning Marriage. State Gazette of 1975 Number 12 